\title{
COMMUNICATION
}

\section{A STUDY GROUP ON THE RUSSIAN REVOLUTION}

Recent years have seen the development in Russian studies of a number of study groups in which specialists meet for the discussion of papers and the exchange of information and ideas. One thinks of the successful launching of the Eighteenth Century, Dostoevsky, and NeoFormalist study groups.

It is time that a similar study group was formed by specialists in the study of the Russian Revolution. The Russian Revolution is now taught in a large number of universities and colleges of higher education in the United Kingdom and abroad, an increasing amount of research is being undertaken, and publications on the subject proliferate; yet existing associations and conferences provide only an occasional opportunity for specialists to meet and exchange views.

A study group on the Russian Revolution would be concerned with political radicalism and related social change during the 19th and 20 th centuries, and with the populist, anarchist, social-democratic, and communist movements in particular. On occasion the group's interests would extend into other periods, but its concern would be with revolution in Russia, and not with the whole of Russian history. Membership of the group would be open to scholars from any country and from any discipline.

It is proposed that the study group should meet annually for two to three days, at a different venue each year, to receive scholarly papers and to discuss developments in the field. A Newsletter would be published and paid for out of a small subscription charge.

In view of the interest which the idea of a study group on the Russian Revolution has already aroused we wish to propose that a first meeting be held at the University of East Anglia in December 1974.

Interested parties are invited to write to John Biggart, School of European Studies, University of East Anglia, Norwich NOR 88C.

John Biggart, University of East Anglia David Collins, University of Leeds

22nd October, 1973

David Longley, University of Aberdeen 